\title{
FFECT OF FOLIAR SPRAY OF HUMIC ACID THROUGH COWDUNG AND VERMICOMPOST WASH ON BIOCHEMICAL PARAMETERS AND YIELD OF \\ GREEN GRAM
}

\author{
Rajesh Deotale, P. Ghadage, S. U. Charjan, P. D. Peshattiwar and V. S. Jayade \\ College of Agriculture, Nagpur, Dr. P.D.K.V., Akola (MS) India \\ Corresponding author Email : rajeshdeotale11@gmail.com
}

\begin{abstract}
The present investigation was carried out at Botany section, College of Agriculture, Nagpur, Maharashtra, India during kharif 2007, to study the effect of different concentrations (100, 150, 200 and $250 \mathrm{ppm}$ ) of humic acid through cowdung and vermicompost wash. Data revealed that two foliar sprays of cowdung wash and vermicompost was at 20 and 35 days after sowing showed their significance over control. Treatment $250 \mathrm{ppm}$ vermicompost wash significantly enhanced chlorophyll and nitrogen content in leaves, protein content in seed, number of pods plant-1, 100 seed weight and seed yield of green gram.
\end{abstract}

\section{Keywords}

Green gram, humic acid, cowdung and vermicompost wash, biochemical parameters, yield

\section{Introduction}

Green gram (Vigna radiata) is one of the pulse crop cultivated in India. Green gram have excellent source of high quality protein. It occupies prominent place in Indian agriculture and its popularity get increased because of its tonnage capacity. Humic acid (HA) is when externally supplied was observed to increase crop growth and ultimately the yield. It improves the nutritional status of soil and plant system. Humic acid application has definite input on protein synthesis and nucleic acid synthesis. The high cation exchange capacity of humic acid prevents nutrient from leaching. It absorbs the nutrients from chemical fertilizers and these exchanges nutrients are slowly released to the plants. Humic acid is the product of break down of organic matter. Humic acid proved many binding sites for nutrient such as calcium, iron, potassium, and phosphorus. These nutrients are stored in humic acid molecules in a form 
readily available to plant, and are released when the plants require them. Humic acid increases the absorption and translocation of nutrients in plants and ultimately influences yield. Humic substances supply polyphenols that catalyze plant respiration and increases root growth. Vermicompost wash is useful as foliar spray. It is transparent pale yellow biofertilizer. It is a mixture of excretory product and mucous secretion of earth worm (Lampito mautriti and Eisenia fetida) and organic micronutrients of soil, which may be promoted as 'potent fertilizer for better growth and yield (Shweta et al., 2005). Vermicompost wash is having approximately $1300 \mathrm{ppm}$ humic acid, $116 \mathrm{ppm}$ dissolved oxygen, $50 \mathrm{ppm}$ inorganic phosphate, $168 \mathrm{ppm}$ potassium and $121 \mathrm{ppm}$ sodium (Haripriya and Poonkodi, 2005). The economic and social potential of livestock in organic agriculture has long been known. In many countries, now a days the major components of organic agriculture is the use of livestock waste such as cow dung and vermicompost in crop production. From far ago cow dung is used not only for therapeutic use but also for organic nutrient elements such as nitrogen, phosphorus, potassium, organic matter and humic acid. It also contains minerals like iron and magnesium which act as fertilizers. Cow dung wash is an excellent liquid manure. It is good source of humic acid

(approximately $1100 \mathrm{ppm}$ ), macronutrients (1.5\% 'N1, 1\% 'P1, 1\% 'K') and also good amount of micronutrients. Farmer who used biogas slurry reports to have obtained higher yield of many crops (Thomas, 2004). But the work on foliar application of humic acid through different sources is merely done and the literature regarding foliar application of humic sources is not sufficiently and scientifically available. Hence, attempt was made to study the effect of foliar application of humic acid sources i.e. cowdung wash and vermicompost wash on biochemical parameters and yield contributing parameters of green gram. 


\section{Material and Method}

The field experiment was conduct in RBD with nine treatments viz., 100, 150, 200 and $250 \mathrm{ppm}$ of HA through cowdung wash and vermicompost wash at experimental farm of Botany Section, College of Agriculture, Nagpur, (MS) India. Cowdung wash and vermicompost wash were sprayed twice at 20 and 35 days after sowing. The experiment was replicated thrice. Leaf chlorophyll and leaf nitrogen were estimated at 35 and 50 DAS. Seed protein content was also estimated. Total leaf chlorophyll content $\mathrm{mg} \mathrm{g}-1$ of the dried leaves was estimated by colorimetric method as suggested by Bruinsma (1982). Leaf nitrogen was estimated by Micro kjeldhal"s method as given by Somichi et al. (1972). Seed protein content was calculated by multiplying nitrogen percentage with the factor 6.25. Observations on number of pods plant-1, 100 seed weight, seed yield plant-1, and plot-1 and harvest index were also recorded.

\section{Result and Discussion}

Data regarding leaf chlorophyll and nitrogen content in seed of green gram are presented in table 1. All the biochemical parameters such as chlorophyll and nitrogen content in leaves recorded at 35 and 50 DAS and protein content in seed were significantly maximum in treatment receiving $250 \mathrm{ppm}$ vermicompost wash. Treatments receiving 250 ppm CDW, 200 ppm VCW, 150 ppm VCW, 200 ppm CDW, 150 ppm CDW and 100 ppm CDW in a descending manner also showed their significance over control. Foliar spray of CDW and VCW enhanced chlorophyll synthesis in the present investigation because the minerals like mg required for chlorophyll synthesis were found adequate in quantity (Sivasubramanian and Ganeshkumar, 2004). Hu and Wang (2001) also reported that Komix humic acid containing organic fertilizers significantly increased chlorophyll content of spring soybean. Unlu et al. (2011) studied the effect of foliar and soil applications with different concentrations $(0,10,20,30$ and $40 \mathrm{ml} \mathrm{1-1)}$ were applied to cucumber plant through either foliar spray or drenching in the root area. Both soil and foliar HA treatments significantly 
increased fruit, skin total chlorophyll content and this effect was mainly on chlorophyll "a" content. The foliar application of humic acid also gave additional major nutrients like $\mathrm{N}, \mathrm{P}, \mathrm{K}$ to the crop and this might have accelerated chlorophyll synthesis. Leaf nitrogen content increased at 35 DAS and decreased at 50 DAS because leaf nitrogen was utilized for different growth processes and developing organs such as seeds do act as strong sink demand may draw heavily the nitrogen from the leaves (Gardener et al., 1998). Poonkadi (2003) also stated that decrease in nitrogen content might be due to translocation and utilization of nutrients for flower and pod formation. The better performance exhibited by humic acid through VCW and CDW in nitrogen content of leaves are in agreement with the earlier results reported by Nandakumar et al. (2004). They reported that foliar application of HA in combination with NPK increased soil nutrients ( $\mathrm{N}, \mathrm{P}, \mathrm{K}, \mathrm{Fe}, \mathrm{Mn}, \mathrm{Zn}, \mathrm{Cu}$ ) availability at all growth stages (fillering, flowering and harvest) in rice.

Although quality of crop products such as oil content, protein content and sucrose content etc. and its appearance is genetically controlled, the nutrition of plants can have considerable impact on the expression of quality. It is therefore, necessary to take care on the nutrient supply at grain formation stage. Protein content of seed is one of the considerable factor for seed quality determination also. Foliar application of HA through CDW and VCW increases the uptake and availability of nutrients and its further association for biosynthesis of protein. This might be the reason for increased protein content in seed in the present investigation. Saurhan et al. (2011) reported that HA treatments increases crude protein concentration while the highest crude protein concentration (13.43\%) was obtain from seeds 33\% + soil 33\% + leaves $33 \%$ fertilization in common millet.

\section{Yield and yield contributing parameters}

Yield and yield contributing parameters such as number of pods plant-1, 100 seed weight and seed yield plant-1 and ha- 1 were significantly maximum in 
treatment receiving $250 \mathrm{ppm}$ VCW when compared with other treatments and control. Also plants sprayed with

\section{Conclusion}

Green gram responded to the foliar application of humic acid i.e. vermicompost wash and cowdung wash. It can be concluded that foliar application of 250 ppm vermicompost wash at 20 and 35 days after sowing enhanced biochemical and yield contributing parameters and ultimately increased yield by $30 \%$ over control. Benefit : cost ratio of the same treatment was 1.96 .

\section{Reference}

Bruinsma, J. 1982. A comment on spectrophotometric determination of chlorophyll. Bio-chem., Bio-Phy., Acta. 52:576-578.

Gardner, F.P., R. B. Pearce and R. L. Mitchell, 1988. Transport and portioning in physiology of crop plants. 2nd Ed. Scientific publishers, Jodhapur, pp. 58-59. Haripriya, K. and P. Poonkodi, 2005. Role of organic mulches and foliar nutrition on changes, nutrient uptake and residual soil fertility in tuberose. Adv. Plant Sci. 18(1): 175-178.

Hu Shuixiu, and Wang Ruizhen, 2001. A study on the effect of komix, humic acid containing organic fertilizer on spring soybean. Acta Agri. Universities Jiangxiensis 23 (4) : 463-466.

Poonakodi, P. 2003. Phosphorus use efficiency in black gram with pressmud. Adv. Plant Sci. 17(1) : 239-241.

Santhi, R., R. Natesan, L. Deverajan and M. Govindaswamy, 2003. Use of coal industries wastes and products on crop production. In short course on ecofriendly recycling of organic and industrial wastes for sustainable soil health. TNAU Department of Soil Science and Agril. Chemistry Agricultural College and Research Institute, Madhurai 625104. 
Saruhan, V., A. Kusvuran, and S. Babat, 2011. The effect of different humic acid fertilization on yield and yield components parformances of common millet (Panicum miliaceum L.). Sci. Res. Essays, 6(3): 663-669.

Shweta, S., K. Yadav, Kiran Kumar and Mamta Sharma, 2005. Vermiwash-A liquid biofertilizer. Uttar Pra. J. 25(1):97-99.

Sivasubramaniam, K. and M. Ganeshkumar, 2004. Influence of vermiwash on biological productivity of marigold. Dept. of Environmental Science. Tamil Nadu Agricultural University, Madras agric. J. 91(4-6): 221-225.

Somichi Yoshida, S. Y. Doughlus and A.P. James, 1972. Laboratory manual. Physiological studies in rice analysis for total Nitrogen (organic N) in plant tissue. The inter. Res. Instti. Los Banos, Languna, Phillipine: 11.

Tangavel, P., R. Balagurunathan, J. Divakaran and J. Prabhakaran, 2003. Effect of vermiwash and vermicast extract on soil nutrient status, growth and yield of paddy. Adv. Plant Sci. 16(1):187-190.

Thomas, J. and T. Ramesh, 2004. Biogas slurry-an excellent liquid manure. J. Spice India. 17(11):24.

Unlu, H.O., H. Unlu, Y. Karakurt, H. Padam, 2011. Change in fruit yield and quality in response to foliar and soil humic acid application in cucumber, Scientific Research and Essays. 6:13, 2800-2803. 
Table 1. Effect of cowdung wash and vermicompost wash on biochemical, yield contributing characters and yield of green gram

\begin{tabular}{|c|c|c|c|c|c|c|c|c|c|c|c|}
\hline \multirow[t]{2}{*}{ Treatments } & \multicolumn{2}{|c|}{$\begin{array}{l}\text { Chlorophyll } \\
\text { content (\%) }\end{array}$} & \multicolumn{2}{|c|}{$\begin{array}{c}\text { Leaf nitrogen } \\
(\%)\end{array}$} & \multirow{2}{*}{$\begin{array}{l}\text { Seed } \\
\text { protein } \\
(\%)\end{array}$} & \multirow{2}{*}{$\begin{array}{l}\text { No. of } \\
\text { pods } \\
\text { plant }^{-1}\end{array}$} & \multirow{2}{*}{$\begin{array}{c}100 \\
\text { seed } \\
\text { weight } \\
\text { (g) }\end{array}$} & \multicolumn{2}{|c|}{ Seed yield } & \multirow{2}{*}{$\begin{array}{l}\text { Percent } \\
\text { increase } \\
\text { in yield }\end{array}$} & \multirow[t]{2}{*}{$\begin{array}{l}\text { B:C } \\
\text { ratio }\end{array}$} \\
\hline & $\begin{array}{c}35 \\
\text { DAS } \\
\end{array}$ & $\begin{array}{c}50 \\
\text { DAS } \\
\end{array}$ & $\begin{array}{c}35 \\
\text { DAS } \\
\end{array}$ & $\begin{array}{c}50 \\
\text { DAS } \\
\end{array}$ & & & & \begin{tabular}{|c} 
Plant $^{-1}$ \\
$(\mathrm{~g})$ \\
\end{tabular} & $\begin{array}{l}\mathrm{Ha}^{-\mathrm{T}} \\
(\mathrm{q}) \\
\end{array}$ & & \\
\hline $\begin{array}{l}\text { Control (Water } \\
\text { spray) }\end{array}$ & 2.131 & 1.687 & 1.77 & 0.92 & 19.10 & 7.50 & 3.78 & 2.12 & 4.59 & 0 & 1.50 \\
\hline $\begin{array}{l}100 \mathrm{ppm} \text { HA } \\
\text { through } \\
\text { wash }\end{array}$ & 2.497 & 1.873 & 2.17 & 1.06 & 20.60 & 9.00 & 4.16 & 2.22 & 4.79 & 4 & 1.57 \\
\hline $\begin{array}{l}150 \mathrm{ppm} \text { HA } \\
\text { through } \\
\text { wash }\end{array}$ & 2.544 & 1.947 & 2.38 & 1.19 & 21.34 & 9.75 & 4.36 & 2.38 & 5.15 & 12 & 1.69 \\
\hline $\begin{array}{l}200 \mathrm{ppm} \text { HA } \\
\text { through } \\
\text { wash }\end{array}$ & 2.608 & 2.025 & 2.91 & 1.89 & 22.12 & 11.25 & 4.68 & 2.46 & 5.32 & 16 & 1.75 \\
\hline $\begin{array}{lr}250 \quad p p m & \text { HA } \\
\text { through } & \text { cowdung } \\
\text { wash }\end{array}$ & 2.779 & 2.229 & 3.55 & 2.45 & 23.34 & 13.25 & 5.09 & 2.67 & 5.76 & 25 & 1.88 \\
\hline $\begin{array}{l}100 \mathrm{ppm} \text { HA } \\
\text { through vermiwash }\end{array}$ & 2.557 & 2.025 & 2.59 & 1.34 & 21.48 & 10.25 & 4.46 & 2.41 & 5.21 & 13 & 1.71 \\
\hline $\begin{array}{l}150 \mathrm{ppm} \quad \mathrm{HA} \\
\text { through vermiwash }\end{array}$ & 2.671 & 2.071 & 3.13 & 2.10 & 22.28 & 11.50 & 4.85 & 2.50 & 5.41 & 17 & 1.77 \\
\hline $\begin{array}{l}200 \mathrm{ppm} \text { HA } \\
\text { through vermiwash }\end{array}$ & 2.681 & 2.133 & 3.33 & 2.25 & 22.82 & 12.00 & 5.07 & 2.61 & 5.66 & 23 & 1.85 \\
\hline $\begin{array}{l}250 \mathrm{ppm} \\
\text { through vermiwash }\end{array}$ & 2.913 & 2.515 & 3.78 & 2.81 & 24.95 & 15.25 & 5.35 & 2.76 & 5.97 & 30 & 1.96 \\
\hline G.M. & 2.598 & 2.056 & 2.85 & 1.78 & 22.00 & 11.08 & 4.64 & 2.44 & 5.31 & - & - \\
\hline $\mathrm{SE}(\mathrm{m}) \pm$ & 0.00094 & 0.00589 & 0.0063 & 0.0029 & 0.022 & 0.4422 & 0.0372 & 0.0184 & 0.0379 & - & - \\
\hline $\mathrm{CD}$ at $5 \%$ & 0.0027 & 0.0172 & 0.0184 & 0.0086 & 0.066 & 1.290 & 0.108 & 0.053 & 0.110 & - & - \\
\hline
\end{tabular}

